\title{
振動法によるケーブル張力測定值へのオープンソケットの影響
}

\section{EFFECT OF OPEN SOCKET ON CABLE TENSION ESTIMATED BY VIBRATION METHOD}

\author{
島田忠幸*·西村＼cjkstart昭**
}

By Tadayuki SHIMADA and Akira NISHIMURA

\begin{abstract}
The method of estimating tension of bridge cables by measuring their natural frequency, so-called vibration method, is convenient on construction site of structures with cables, Concerning the method some papers have been reported hitherto. In these reports cables are assumed to be clamped on both ends. However, for the estimated tension of cable supported by open sockets, vibration of the sockets has a notable effect, which has not been investigated. In order to get reliable and accurate estimation for tension of cables with open socket, some experimental works were performed and reported in this paper.

Keywords : open socket, vibration method, cable tension
\end{abstract}

\section{1. 諸言}

ケーブルの振動数を測定して張力を求めるいわゆる振 動法は，ロードセルあるいは油圧ジャッキを利用する測 定法と比較して測定法が圧倒的に簡単であることから， ケーブルを組み込んだ橋梁の架設工事のほか, これらの 維持管理を目的とした測定にも適用が期待されている.

この測定法の実用化を目的として, 新家ら ${ }^{1)}$ は, 測定 した振動数から張力を求めるときの実用算定式について の提案を行っており, 島田・西村 ${ }^{2}$ は, 振動法に関連し てケーブル曲げ剛性を実験的に求める際の問題点につい て，報告を行っている.

これらの報告はいずれも, ケーブル端部の支点拘束条 件を固定とみなして考察を行っている. しかし, 端部に オープンソケットのついたケーブル張力を振動法で測定 するとき, 直径に比して長さが短いケーブルについては オープンソケットの振動が生じて固定条件とはみなせな くなるが，この面の報告はなされていない、このような ことから, 本論文は振動法の実用化を目的として, オー

* 正会員 石川島検查計測 (株) ( T135 東京都江東区豊洲 1-2-40)

** 正会員 工博 神戸大学教授 工学部土木工学科 ( 于657 神戸市灘区六甲台町 1 )
プンソケットのついたケーブルの支点条件について，実 験的検討を行ったものである.

\section{2. 実験方法}

実験に用いたケーブルは，長大吊橋およびニールセン 橋の吊材などに一般に用いられるものとして, 直径 56 $\mathrm{mm}$ のロックドコイルケーブルおよび, 直径 $58.5 \mathrm{~mm}$ のスパイラルケーブルを用いた。オープンソケットは ケーブル径から決定される通常の大きさのもの（図一1, 図一7）を用いた。オープンソケットの振動がケーブル
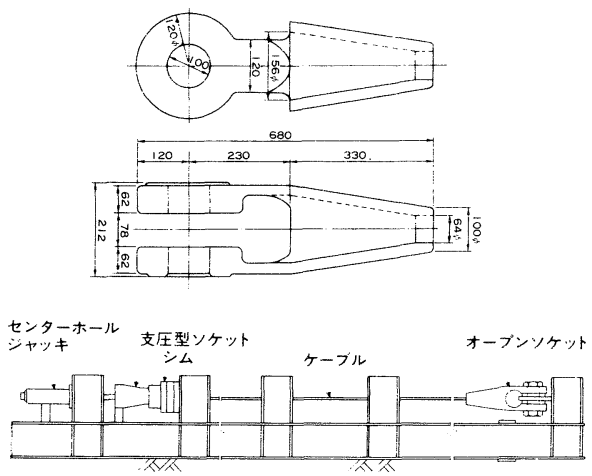

図一1 オープンソケットおよび実験装置（実験一1） 
の振動に与える影響は, 回転ヒンジ方向よりも回転ヒン ジ直角方向の方が少ない，したがって，ケーブルの固有 振動数は回転ヒンジ直角方向の值を計測した。

本実験は, 直径に比較してケーブル長さが短くなると き,オープンソケットに振動が生じて支持条件が変化し ないかどうかの検討が目的である.しかし,この場合ケ一 ブルの振動数は曲げ剛性の影響を大きく受けるので，こ の影響をも合わせて検討することが必要になる.

\section{(1) 実 験 -1}

実験一1 では，直径に比較して長さの長いケーブルを 対象に，一端に支圧型ソケット他端にオープンソケット のついた，長さ $13.5 \mathrm{~m}$ および $9.1 \mathrm{~m}$ のロックドコイル ケーブルを供試体に選定した。張力は，振動法とソケッ ト受け台にはり付けたストレインゲージから求める 2 方 法で測定した。なお，後者の測定は，センターホール ジャッキを用いて測定值の較正を行った。ケーブルの振 動数は，サーボ型加速度計を用いて，ハンマーで軽く衝 撃を与える強制加振法と常時微動法から測定を行った.

図一1に実験装置を示す。ケーブル諸元を以下に示す.

直径 : $56 \mathrm{~mm}$

曲げ剛性 : $5.0 \mathrm{tm}^{2}$

単位長さ重量 : $17.8 \mathrm{~kg} / \mathrm{m}$

断面積 $\quad: 0.00203 \mathrm{~m}^{2}$

ケーブルの曲げ剛性は新家らの実験結果 ${ }^{11}$ 参考とし て，ケーブルと等径の棒材の曲げ剛性の $50 \%$ を有効と 考えた。ケーブルの曲げ岡性は支点拘束条件の影響を受 けるが，供試体に用いたケーブルは直径に比較して長さ が十分長いので, 曲げ剛性の設定誤差が測定結果に与え る影響は無視できる ${ }^{2)}$.

(2) 実験 -2

実験一 2 は, ケーブル径に比較して長さの短いケーブ ルを対象に, 長さ $2.48 \mathrm{~m} と 1.5 \mathrm{~m}$ の 2 本のスパイラル ケーブルを供試体に選定した。ケーブル諸元を以下に示 す.

\section{直径 $\quad: 58.5 \mathrm{~mm}$ \\ 断面積 $\quad: 0.00205 \mathrm{~m}^{2}$}

単位長さ重量: $17.2 \mathrm{~kg} / \mathrm{m}$

図一2に実験装置を示す。撚りのあるケーブルに張力 を導入するとき，ケーブルは撚りが戻る方向に回転す る4)ので，曲げ岡性が変化する.

しかし，実橋ケーブルでは，端部のオープンソケット は回転しない，本実験では，拘束条件を実橋と同じにす るため, 張力導入時はケーブル軸線まわりのオープンソ ケットの回転を支持板で拘束して軸方向だけの変位を許 し，導入後は回転止めボルトを締めて軸線まわりのオ一 プンソケットの回転および変位を拘束した（図一2）.

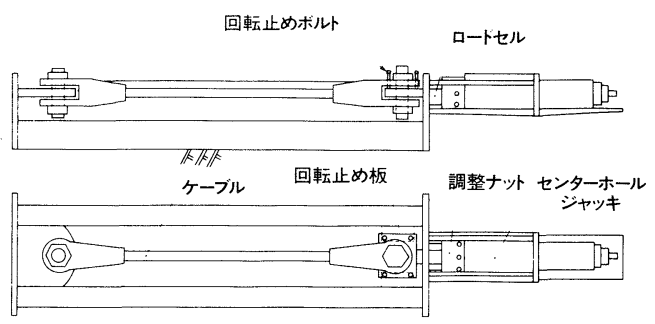

図-2 実験装置（実験-2）

\section{3. 実験結果}

\section{(1) 実 験 - 1}

図一3に実験結果を示す．計算值はケーブル両端を固 定として，長さ： $l$ を図中に定義したときの值を示す. 振動法と計算值はよく一致している．特に，常時微動法 の方が計算値よよく一致している.これらの測定結果よ り，ケーブル径に比較して長さの長いときは，ケーブル の両端を固定としても問題のないことがわかる.つまり， ケーブルとオープンソケットとの剛比が著しく小さいの で，オープンソケットの振動の影響は生じない.

実験一1では，これらのケーブルのほかに長さ 3.36 $\mathrm{m}$ のケーブルについても実験を行った。このときは， オープンソケットの支持板の振動がみられ，実験結果と 計算値とは一致していない。これは実験装置の剛性の小 さいことが考えられ，実験一2では実験装置の剛性に留 意して, 長さの短いケーブルを対象に別途実験を行った.

\section{(2) 実 験 一 2}

図一4 は，ケーブル長さ $2.48 \mathrm{~m}$ のときの実験結果を 示す.図中, 計算值は式 (1) に示すケーブルの換算曲 げ剛性比 $k$ が $0.50,0.55 ， 0.60 ， 0.65$ の場合についに, ケーブルの両端を固定と仮定したときの值を示す。

$$
k=\frac{E I_{c}}{E I_{b}}
$$

$E I_{c}:$ ケーブルの曲げ剛性

$E I_{b}:$ ケーブルと等径の棒材の曲げ剛性

$E$ はケーブルと棒材の材料の弾性係数で, $2.1 \times 10^{7}$ $\mathrm{tf} / \mathrm{m}^{2}\left(2.06 \times 10^{6} \mathrm{kN} / \mathrm{m}^{2}\right)$ とする。

図中，○印は張力をまったくかけない第 1 回目の実験 結果であり，○印は第 2 回目，口印は第 3 回目の実験結 果である. 第 1 回目での $k$ は, ほぼ 0.55 の計算曲線に 対応している. 第 2 回目と第 3 回目ではデータの再現性 がみられるが，第 1 回目とは大きな差違が生じている. プリテンションによって曲げ剛性が著しく変化している ことがわかる.

図一 $5^{21}$ は，断面径および撚りの状態がまったく同一 である長さ $3.5 \mathrm{~m}$ のケーブルについて，振動法によつ て求めた曲け剛性の実験結果を示す。図中, 


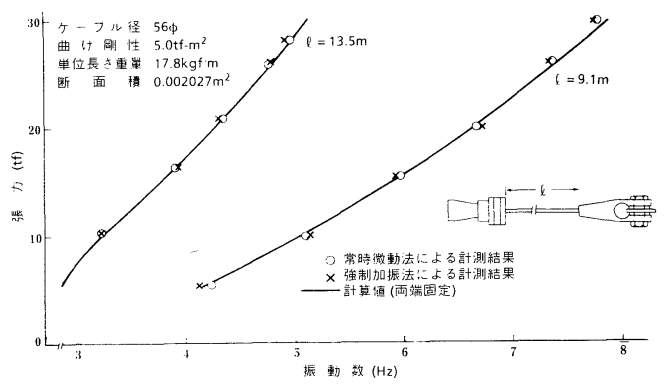

図一3 実験結果（実験一1）

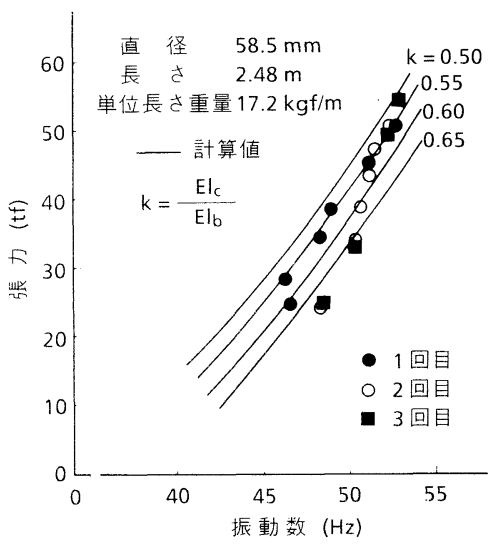

図一4 実験結果（実験一 $2 ：$ 長さ $2.48 \mathrm{~m}$ )

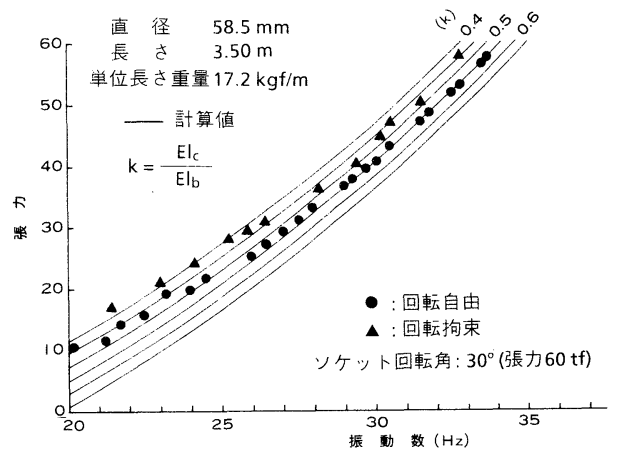

図一5 ケーブル曲げ剛性の実験結果 ${ }^{2)}$

プンソケットの回転が自由のとき， $\boldsymbol{\Delta}$ 印は拘束のときを 示している. 回転を拘束した場合, ケーブル張力が 30 tf 以上では， $k$ は 0.45 に近い計算曲線に対応している.

図一 4 において，プリテンションの影響のない第 1 回 目について考えてみると， $k$ はほぼ 0.55 の計算曲線に 対応している.オープンソケットに振動が生じたときは 見掛けの $k$ は小さくなる.しかし，図一 4 に示す実験值 (k) は, 図一5に示す実験值より大きいことから，オー プンソケットの振動は生じていないといえる.

図一4では, 張力の低いところで第 2 回目(○印), 第 3 回目（口印）の曲げ剛性が大きくなっている．これ
は，プリテンションによって撚りの状態が変化し, 張力 を解放しても元の状態に戻らないことを示している. し かし, 長さ $3.5 \mathrm{~m}$ のケーブルではこのような現象は観 察されなかった。

また，曲げ剛性はケーブル長さが長くなると小さく なっている．これは，ケーブルに曲げモーメントが作用 すると素線相互間が滑動し，断面が分離して曲げ剛性が 減少する ${ }^{5}$. しかし, 長さの長いケーブルの方が曲げモー メントが大きくなるので，断面分離が大きくなり，その

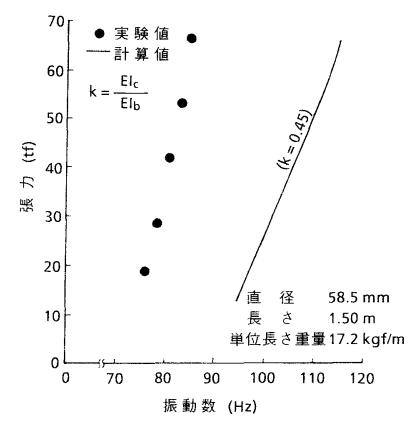

図一6 実験結果 (実験一2：長さ $1.5 \mathrm{~m}$ )

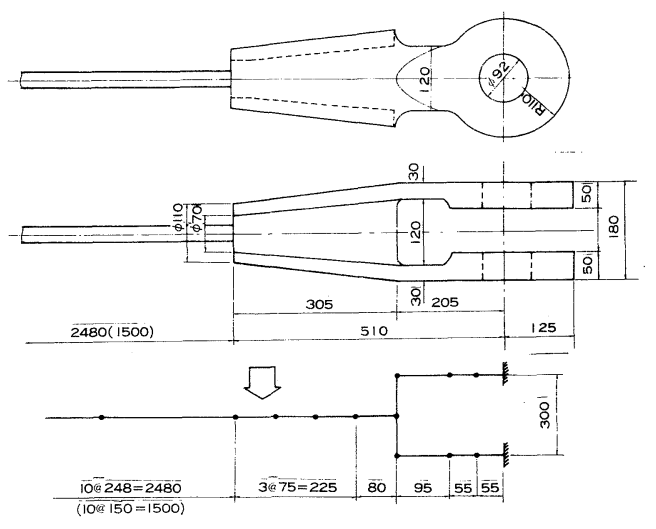

図一7 オープンソケットおよびモデル化

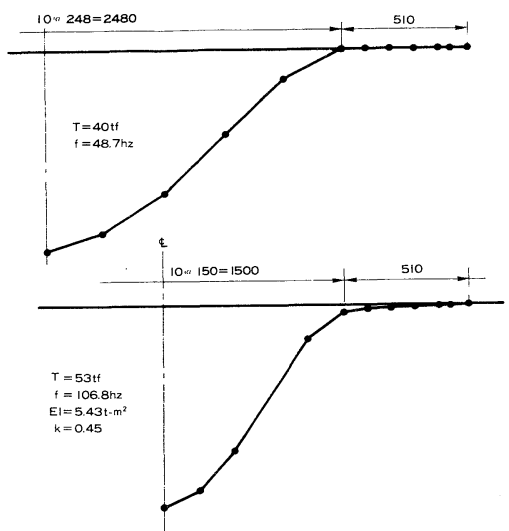

図一8 計算結果 
結果曲げ剛性の小さくなることが考えられる。

図一6は，長さ $1.5 \mathrm{~m}$ のケーブルについての実験結果 を示す。このときは明らかにソケットの振動が生じてい ることがわかる。

次に，オープンソケットとケーブルの連成振動につい て有限要素法にて計算を行い，上記の実験結果と対比す る. 図一7に，このときのモデル化を示す．ソケットは 回転ヒンジで固定と仮定し，オープンソケットの質量お よび曲げ岡性には,ソケットメタル充壃部 (亜鉛) をも 考慮した. 充填部中央の曲げ剛性は $293 \mathrm{tf} \cdot \mathrm{m}^{2}$ となり, ケーブルの約 49 倍になっている.

図一8に，ケーブル張力として実験時の代表値を選定 したときの固有振動モードの計算結果を示す。ケーブル 長さが $2.48 \mathrm{~m}$ のときは, オープンソケットの振動は生 じていないが, 長さが $1.5 \mathrm{~m}$ のさき振動が生じてい る.

このとき, ケーブル張力 : $53 \mathrm{tf}$ のききの有限要素法 による計算值：106.8 Hz は，ケーブル両端を固定とし た計算値（図一6）とほぼ一致するが, 実験值とは大き く異なる.これは, 回転ヒンジのところでオープンソケッ トが固定にならないことを示している.

以上, 直径に比して長さの長いケーブルでは, 両端を 固定と考えても問題はないが, 長さが短くなると, オー プンソケットの振動の影響の生じることが明らかになっ た.このような場合, 振動法の適用は困難であるが，そ れ以前にオープンソケットの振動の影響が生じるケーブ ル長さの判定が必要になる。具体的には，ニールセン橋 両端部の吊材が問題となるが，ケーブル本数としてもご く少数であるので, 油圧ジャッキ等の直接的な測定法と 併用することが実際的な解決法と考えられる.

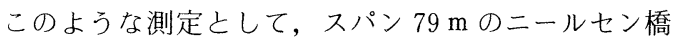
の吊材張力の測定例の報告がある ${ }^{3)}$. 端部の吊材だけは 長さが短いので, 油圧ジャッキを用いて測定を行ってい るが，その他の吊材はオープンソケットで固定されてい ると考え，振動法にて測定を行っている．最終的な張力 測定値は，設計張力の $5 \%$ 以内となっている.

\section{4. まとめ}

オープンソケットの付いたケーブル張力を振動法で測
定するときのケーブル端部の拘束条件について，実物大 ケーブルを用いた実験的検討を行った．得られた結果は 下記のとおりである。

（1）ケーブル長さが直径に比較して十分長いとき, ケーブル両端を固定として張力を計算することができ る.

（2）ケーブル長さが直径に比較して極端に短くなる と, オープンソケットの振動による影響の生じることを 実験的に確認した.

（３）オープンソケットの振動による影響は，オープ ンソケットの寸法にも関係するが，回転ヒンジの所で オープンソケットが固定にならないことによる影響の大 きいことが, 実験結果と有限要素法による計算結果から 推定できる。

（4）このようなことから，オープンソケットで支持 されたケーブル張力を振動法で測定するとき, 適用可能 なケーブル長さには制限が生じる.しかし，オープンソ ケットの振動の影響が生じるような測定の頻度として は，非常に少ない。

\section{参 考 文 献}

1）新家 徹・広中邦汎・頭井 洋・西村春久：振動法によ るケーブル張力の実用算定式について, 土木学会論文報 告集, 第 287 号, pp. 32 36, 1979 年 7 月.

2）島田忠幸・西村 昭：振動法によるケーブル張力測定値 への曲げ剛性の影響, 土木学会論文報告集, 第 398 号, pp. 409 412, 1988 年 10 月.

3）島田忠幸・原＼cjkstart公・柴田秀夫：テンションメータによ るケーブル張力の測定, 応力・ひずみ測定シンポジュウ 么講演集, 第 16 号, pp. $41 \sim 44$, 昭和 58 年.

4）会田俊夫・佐藤 進・中井幹雄：多層よりスパイラル ロープの自転性について, 日本機械学会論文報告集, 第 34 巻, 第 258 号, pp. $355 \sim 361$, 昭和 43 年 2 月.

5）会田俊夫・佐藤 進：鉱索に生じる最大曲げ応力につい て, 日本鉱業会誌, 第 76 巻, 第 870 号, pp. 915 919, 昭和 35 年 12 月.

(1989. 9.14 - 受付) 